\title{
タフトライドした SKD 11 の表面の耐摩耗性*
}

\author{
中 沢 洋 二** 寺 沢 正 男** \\ 吉 岡 靖 夫** 浅 見 克 敏**
}

Wear Resistance of Tufftrided Die Steel, SKD 11

by

\author{
Youji Nakazawa, Masao Terasawa, Yasuo Yoshioka and Katsutoshi Asami \\ (Musashi Institute of Technology, Tokyo)
}

It has been reported in the past that the tufftriding treatment improves the wear resistance of the iron and steel. For this reason, the tufftrided alloy tool steel is being widely used as the dies material for plastic working. However, its wear characteristics are hardly clarified.

In the present study, the wear characteristics of the alloy tool steel (SKD 11) treated in various tufftriding time are investigated to find the most suitable tufftriding time.

The following conclusions have been obtained.

(1) The compound layer composed of two sub-layers is formed at the surface of specimen by the tufftriding treatment. The composition of the outside sub-layer is mainly the nitride of $\mathrm{Fe}$ $\left(\mathrm{Fe}_{3} \mathrm{~N}, \varepsilon \mathrm{Fe}_{3} \mathrm{~N}-\mathrm{Fe}_{2} \mathrm{~N}\right)$ and that of the inside sub-layer is mainly the nitride of $\mathrm{Cr}\left(\mathrm{CrN}, \mathrm{Cr}_{3} \mathrm{~N}\right)$.

(2) The diffusion layer is formed under the compound layer, and both nitride and carbide are observed at the grain boundary in the diffusion layer.

(3) The hardness value of the outside compound layer is lower than those of the inside compound and diffusion layers, and the outside compound layer comes off easily by the dry wearing at the room temperature.

(4) The inside compound and diffusion layers contribute to the improvement of wear resistance, and the wear resistance is improved most when the specimen is tufftrided for about 12 hour.

(Received Mar. 22, 1975)

\section{1 緒言}

最近軟窒化法の一種であるタフトライド処理法は浸 炭や高周波焼入れなど他の表面硬化法に比べて低温処 理 $\left(570^{\circ} \mathrm{C}\right)$ であるため寸法変化が少なく，処理後に 最終仕上げすることなくただちに使用できるなどの利 点をるつため一般広く用いられつつある. 特佰型用 合金工具鋼のように耐摩耗性，耐かじり性，耐焼付け 性が要求される場合には従来浸炭, 窒化, 高周波焼入 れなどが用いられてきたが, タフトライト処理のほう がより有効であった報告もされている. 従来のタフト ライド処理に関する研究は付疲労性に関するるのが多 く, 耐摩耗性に関するものは比較的少ない。しかし, 実際には耐摩耗性, 而かじり性, 耐焼付け性の面に数

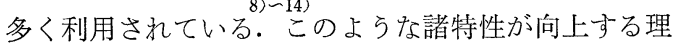
由としては定性的には表面近傍に形成される複合窒化

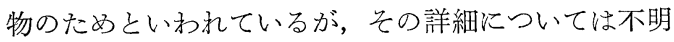

* 原稿受理 昭和 50 年 3 月 22 日

** 正会員 武蔵工業大学 東京都世田谷区王堤
な点が多い。また，タフトライド処理時間によってか たさや摩耗特性等の諸性質は変わることが予想され， 最適な処理時間があるものと思われる.

そこで著者らはこれらについて検討することにした． 本報では第一段階として冷間用金型材である合金工具 鋼 SKD 11 を用いて組織観察, X線分析，かたさ測 定, 摩耗試験などよりタフトライド処理によって形成 される複合窒化物の挙動を調べたとてて合金工具鋼 の摩耗に及洁すタフトライド処理の影響および最適処 理時間について検討した。

\section{2 実 験 材 料}

本実験に使用した材料は，合金工具鋼 SKD 11 (冷 間金型用）で，その化学成分を Table I に，試験片 形状和よび寸法をFig. 1 亿示す. 試験片No.1 は, 夕 フトライド処理時間 $(0.5,1,1.5,2,4,6,8$, $10 ， 15 ， 20 ， 30 ， 36$ 時間）に上る表面かたさと断面 かたさ分布を調べるのに用いた，試験片 No.2 は，摩 耗試験に用い, タフトライド処理時間は, 試験片 No. 
Table I. Chemical compositions of specimen (\%).

\begin{tabular}{c|c|c|c|c|c|c|c}
\hline $\mathrm{C}$ & $\mathrm{Si}$ & $\mathrm{Mn}$ & $\mathrm{P}$ & $\mathrm{S}$ & $\mathrm{Cr}$ & $\mathrm{Mo}$ & $\mathrm{V}$ \\
\hline 1.52 & 030 & 0.40 & 002 & 001 & 11.93 & 0.8 & 032 \\
\hline
\end{tabular}

No.I
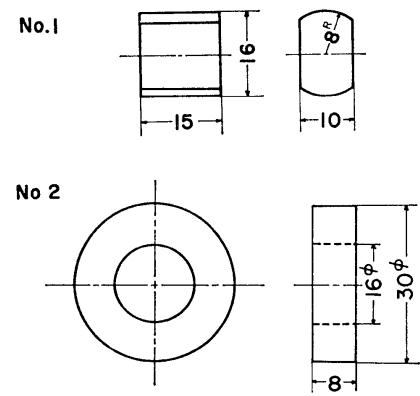

F1g. 1. Shape and dimension of specimen.

1 と同じである.このほかにX線分析用として $10 \times 10$ $\times 30 \mathrm{~mm}$ の試料を準備した。なお，摩耗試験の相手材 としてはS 45 C の焼入筅もどし材 $\left(H_{V} 750\right)$ を用いた. タフトライド処理用の試験片は, 機械加工後 $850^{\circ} \mathrm{C}$ 真 空燒なましを行ない, $1050^{\circ} \mathrm{C}$ 焼入（空冷）後 $-73^{\circ} \mathrm{C}$ サブゼロ処理を施し， $170^{\circ} \mathrm{C}$ 暁もどしを行なった後タ フトライド処理を施した。

タフトライド処理に使用した忓は，直径 $600 \mathrm{~mm}$, 深さ $1000 \mathrm{~mm}$ の空気吹込及式のチタンポットで, 塩 浴の組成を Table II に示す. 試験片のタフトライ ド処理方法は，まず，長時間処理の試験片より順次 $570^{\circ} \mathrm{C}$ の塩浴中飞浸せきし，忓より出す時期をすべて 同一にした，そのため，塩浴の窒化能力は時間ととも 飞若干劣下（約 36 時間で $\mathrm{KCN}, \mathrm{KCNO}$ が $4 \sim 5 \%$ 低下）するが，各処理時間の試験片に対する劣下の影 響は無視できると考光る。 $570^{\circ} \mathrm{C}$ 塩浴中に，所定の時 間保持した後, $180^{\circ} \mathrm{C}$ の油中で泠却した. また，タフ トライド処理材と比較するために燒入，焼もどしのみ でタフトライド処理を施さない試験片も用意した。

Table II. Chemical compositions of salt for tufftriding.

\begin{tabular}{c|c|c}
\hline KCN & KCNO & $\mathrm{Na}_{4} \mathrm{Fe}(\mathrm{CN})_{6}$ \\
\hline 520 & 42.25 & 0.17 \\
\hline
\end{tabular}

\section{$3 \cdot 1$ 組織観察}

\section{3 実 験 方 法}

組織観察については, タフトライト処理時間を変え た場合の断面を観察した．観察部分はダイヤモンド゚ 一ストにより研摩した後腐食した。腐食液は $\mathrm{HNO}_{3}$ ：
$10 \mathrm{cc}, \mathrm{HCl}: 30 \mathrm{cc}, \mathrm{CH}_{2} \mathrm{OH}: 30 \mathrm{cc}$ の割合のものを 使用した。観察には走査型電子顕微鏡を用いた。

\section{$3 \cdot 2 \mathrm{X}$ 線分析}

タフトライド処理により新たに形成される組織の組 成についてはX線分析を行なった．分析には試験片の 最表面より内部に向かって数ミクロンずつ化学研摩で 除去しながら，そのつぞ新たな表面について行なっ た。同定は ASTM カードによった。化学研摩には $\mathrm{HF}: 15 \mathrm{cc}, \mathrm{H}_{2} \mathrm{O}_{2}: 170 \mathrm{cc}, \mathrm{H}_{2} \mathrm{O}: 7 \mathrm{cc}$ の溶液を用い た. また，定性的な元素分析についてX線マイクロア ナライザを用いて行なった.

\section{$3 \cdot 3$ かたさ測定}

試験片 No.1 を用いて，表面かたさと断面かたさ分 布に対するタフトライド処理時間の影響を調べた．表 面かたさは最表面を若干ダイヤモンドペーストにより 研摩を行ない，微小硬度計（荷重 $100 \mathrm{~g}$ ）でかたさ測 定を行なった。な批较のためタフトライド処理して いない焼入焼もどし材についても同様の測定を行なっ た。

\section{$3 \cdot 4$ 摩耗試験}

摩耗試験には,すべり摩耗タイプの西原式摩耗試験 機を用いた。試験条件は常温乾燥式両回転で, 压縮荷 重 $100 \mathrm{~kg}$, 回転数 800 r. p. m., ずべ度 $9.09 \%$ で行 なった．摩耗量の測定は 0.5 時間ごとに試験片を取り はずし, 重量, 外径を化学てんびんとマイクロメータ に上り測定した。摩耗試験の相手材（S45C）はタフ トライド処理材に比べて軟かいために摩耗試験中に変 形が起こりやすく, 真円度が悪くなって摩耗試験が困 難になるので，外径の最大值と最小值の差が $60 \mu$ とな ると交換し，タフトライド処理材が同椂になったとき をもって摩耗試験の限界とみなし実験を終了した。

\section{4 実験結果および考察}

\section{$4 \cdot 1$ 組織}

Fig. 2 は，タフトライド処理していない燒入燒もど し材拉よびタフトライト処理時間が異なる場合の断面 組織である.タフトライド処理されると，表面近傍に 数片の化合物層ができ，さらに粒界に沿って化合物が 網目状に浸入した拡散層が存在する。化合物層, 拡散 層ともタフトライド処理時間が長くなる注ど厚くなる。 12時間処理について最外表面より内部に向かってX 線分析を行なった回折波形をFig. 3 飞示す. 図中に 表面からの距離を示してあるがX線による透過度は2 $\theta$ あるいは検出物によって多少違らが $5 \mu$ 程度内部組成 も検出している．Figs. 2 および 3 の結果より表面近 傍の化合物層は主として $\mathrm{Fe}$ の窒化物である $\mathrm{Fe}_{3} \mathrm{~N}$, $\varepsilon \mathrm{Fe}_{3} \mathrm{~N}-\mathrm{Fe}_{2} \mathrm{~N}$ で形成されていると思われ，その直下に は $\mathrm{Cr}$ の窒化物である $\mathrm{Cr}_{3} \mathrm{~N}$ も存在している. そして, 化合物層の直下の拡散層には $\mathrm{CrN}$ と $\mathrm{Cr}_{7} \mathrm{C}_{3}$ がみられ 


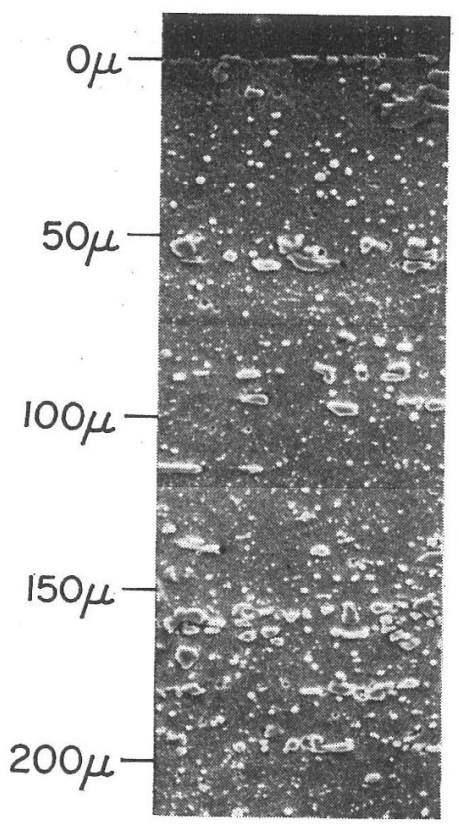

(a) Ohr

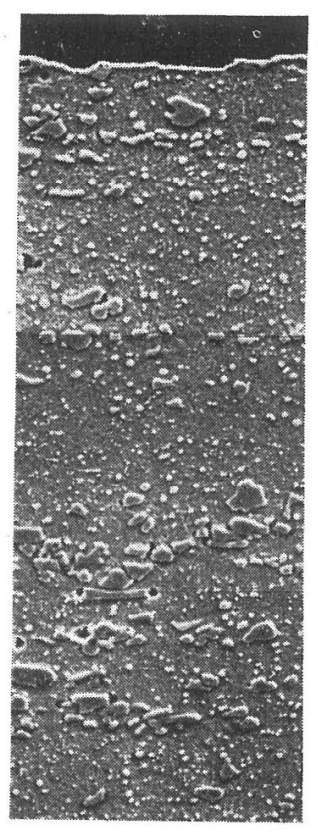

(b) $0.5 \mathrm{hr}$

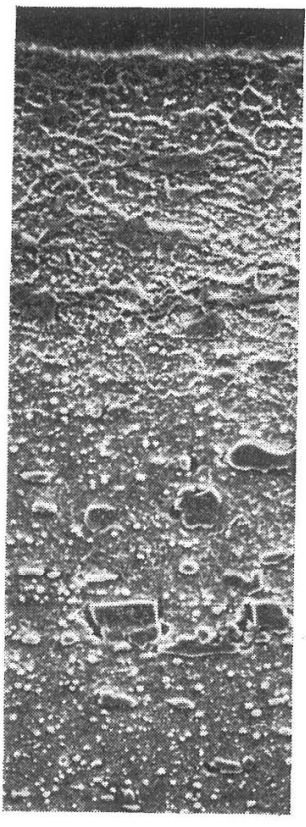

(c) $12 \mathrm{hr}$

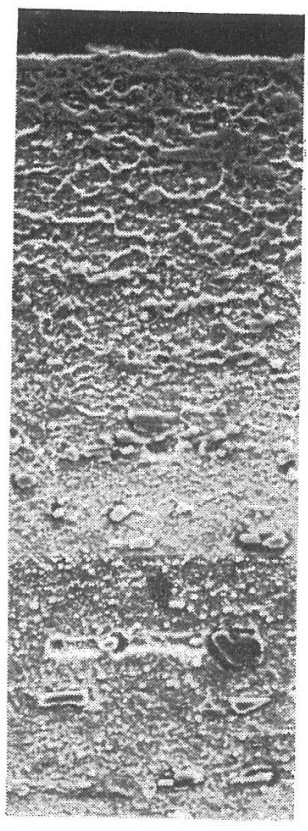

(d) $36 \mathrm{hr}$

Fig. 2. Variation of sectional microstructure with tufftriding time.

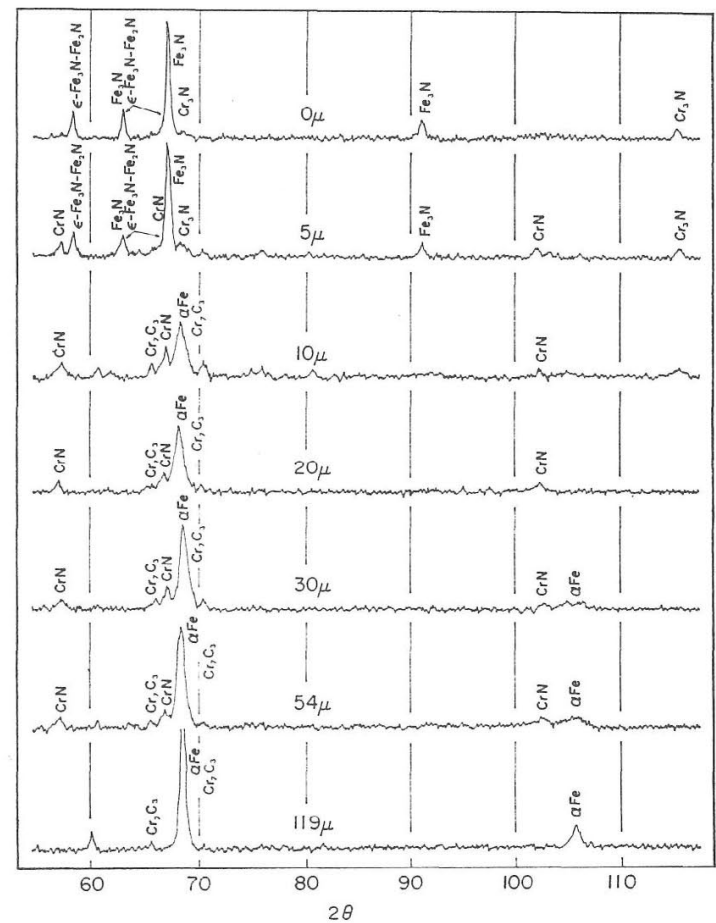

Fig. 3. Diffraction intensity curves toward depth ( $\mu$ ) from surface of tufftrided specimen.

る。 CrN は内部に入るに従い減少し, 表面より $54 \mu$ では若干存在しているが，119 ルになるとみられない。 一方，Fig. 2 の組織写真から明らかなよらに粒界に沿
って浸入している化合物は70～80 $\mu$ で消失して扣り， Fig. 3 の $\mathrm{CrN}$ の結果とよく対応している.したがっ て，この粒界に沿って浸入している化合物は主として $\mathrm{CrN}$ と洘光られる。 $\mathrm{Cr}_{7} \mathrm{C}_{3}$ は SKD 11 自体に存在す るものであるが，後述のよらにタフトライド処理によ っても浸炭效果が若干あるようである。また，ASTM カードで同定できない窒化物も若干あった。

$\mathrm{Fe}, \mathrm{N}, \mathrm{Cr}, \mathrm{C}$ について表面より内部へ元素分析を

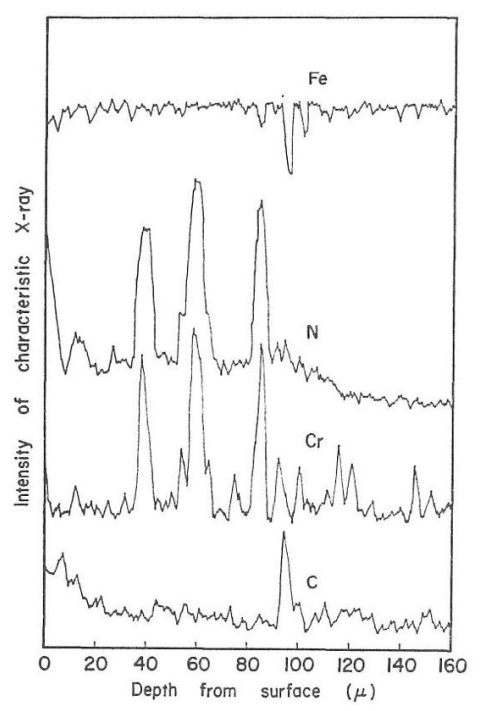

Fig. 4. Element analysis of 12 hours tufftrided specimen. 
行なった結果を Fig. 4 に示す。 N, $\mathrm{Cr}$ とも同じ場所 で高い回折強度尔しているのは, Fig. 2 の断面組織 でるみられたよらに，粒界に沿って形成された窒化物 ( $\mathrm{CrN})$ にると考觉られる。缮峨らによると，ホース テナイト系高 Cr 鋼に掠いて, 浸炭作用が起こると報 告されて招り，本実験に括いてもCは内部よりも表面 近傍の回折強度が高く、タフトライド処理を施すこと によりわずかであるが浸炭効果が珰められる。また， Fig.3 のX線分析でるみられる $\mathrm{Cr}_{7} \mathrm{C}_{3}$ の回折強度も内 部より化合物直下で高く, 浸炭効果子裏付けている。

\section{2 功たさ}

断面かたさ分布の一例として12時間処理した場合を Fig. 5 に示す。タフトライド処理を行なかない焼入焼 もどし材のかたさ值 $\left(H_{V} 780\right)$ に比べて表面近くの化 合物層直下は約 $H_{V} 1200$ と著しくかたさが上昇して いる. そして表面から内部に向かってかたさは低下し， その後一定值になる. 本報ではこの一定值を心部のか たさ，一定值になる表面からの距離を硬化深さと定義 した.

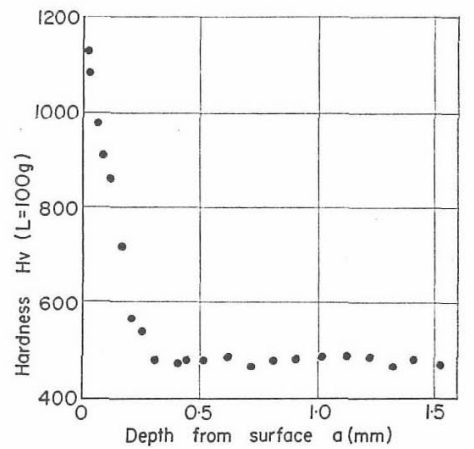

Fig. 5. Sectional hardness distribution of 12 hours tufftrided specimen.

最表面の化合物層のかたさ值は，その厚さが約10

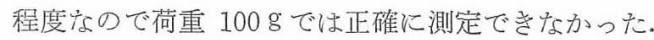
そこで化合物層の部分を約15度にテーパーカットし，

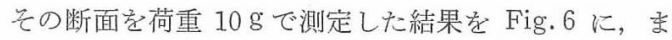
た压痕形状を Fig. 7 に示す。最表面に近いかたさ值 は，約 $H_{V} 400$ を示した。これは干痕が端面に接近し ずぎているためか，多孔質であるためか，㐫るいは材 質的に軟かいのかその理由は明らかでないが，その点 苍除くと約 $H_{V} 600$ である. そして, 最表面より7〜8 $\mu$ で最高值を示し，拡散層表面と思われる $10 \mu$ 付近で 約 $H_{V} 1200$ を示している.

この化合物層は，Fig. 3 のX線分析結果より最表面 近くは主として $\mathrm{Fe}$ 䇪化物 $\left(\varepsilon+r^{\prime}\right.$ 相)であり，その 下は $\mathrm{Cr}$ 窒化物を主体としている二相からなると考え られる。従来，窒化鋼にガス窒化を施すと最表面には

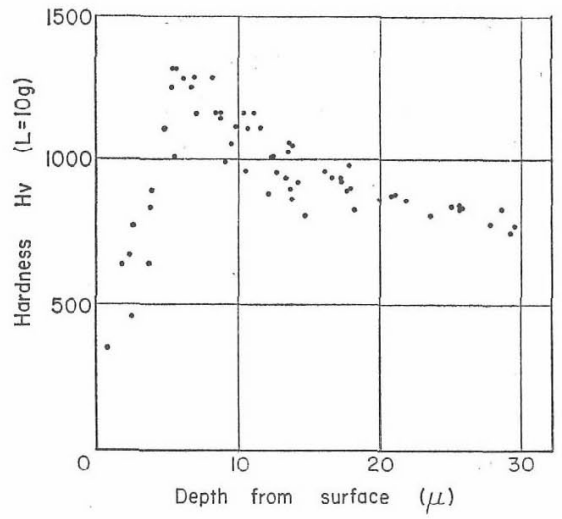

Fig. 6. Sectional hardness distribution of nitride layer of 12 hours tufftrided specimen.

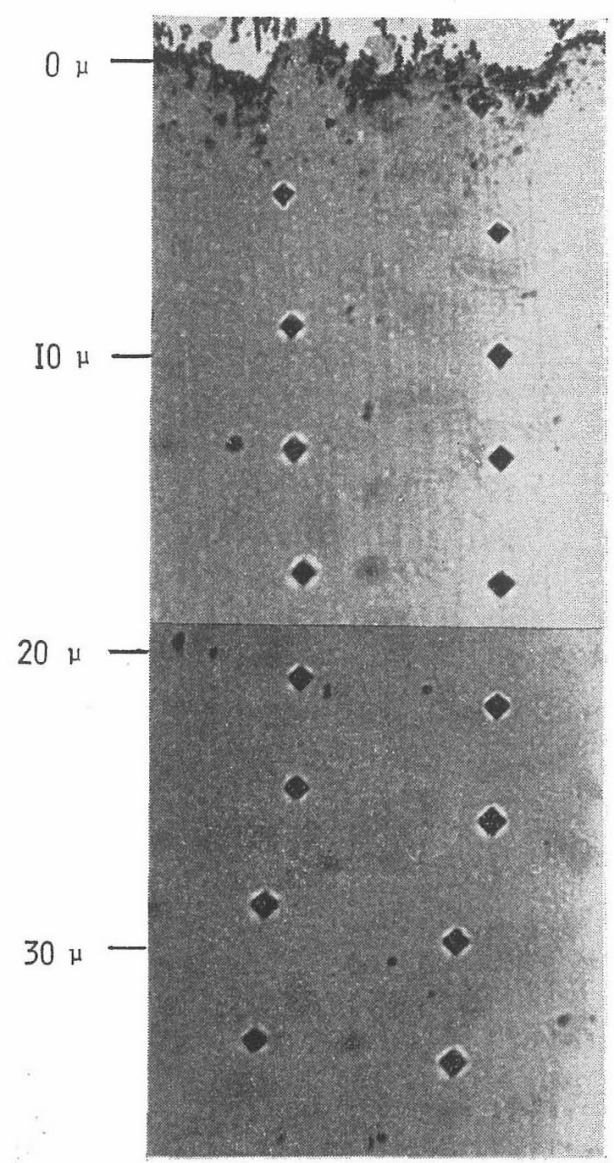

Fig. 7. Vickers hardness marks of nitride layer of 12 hours tufftrided specimen.

$\varepsilon+\gamma^{\prime}$ 相の化合物層が形成され，气の下は $\mathrm{Cr}, \mathrm{Al}$ な どの窒化物が微細に析出している払散層であり，最表 面のX線分析では $\mathrm{Cr} ， \mathrm{Al}$ などの窒化物は同定されな いといわれている。そして， $\varepsilon+\gamma^{\prime}$ からなる化合物層 のかたさ值は約 $H_{V} 750$ 〜 800 で，拡散層のかたさ值は 約 $H_{V} 1200$ と化合物層のほうが低いと報告されてい 
る。また，炭素鋼にタフトライド処理，西るいはガス 軟窒化处理すると最表面に $\varepsilon+\gamma^{\prime}$ 窒化物からな尚化合 物層が形成され，化合物層の直下には窒素を $\alpha$ 鉄中に 過飽和固溶したり， $r^{\prime}-\mathrm{Fe}_{4} \mathrm{~N}$ として析出したりしてい る拡散層が形成される。そしてタフトライド処理では 化合物層のかたさ值は約 $H_{V} 600$, ガス軟空化处理で は約 $H_{V} 750$ であり, 拡散層 $\left(H_{V} 200 \sim 400\right)$ よりかた さ值は高いと報告されている。

本実験の SKD 11 にタフトライド処理した場合には すでに述べたように最表面にできる化合物層のうち一 相目の $\mathrm{Fe}$ 窒化物は約 $H_{V} 600$ で山り, その真下涳 素との親和力の大きい Cr 空化物を主とした二相目が 存在し，そのかたさ值は約 $H_{V} 1300$ と高い。また， 桩散層には粒界飞沿って $\mathrm{Cr}$ 窒化物, あるいは $\mathrm{Cr}$ 炭 化物が浸入して特り，窒素の固溶子亦るため $\mathrm{Fe}$ 窒化 物よりなる化合物層（一相目）よりも，かなり高いか

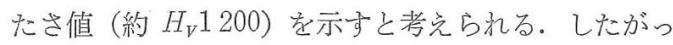
て窒化処理されるとその处理方法にかかわらず多くの 鉄鋼材料ではとの最表面に $\mathrm{Fe}$ 窒化物からなる化合物 層が形成されることがわかる。皇して，そのかたさ值 は約 $H_{V} 750$ 程度之考克ら机る。な秥, タフトライド 処理で化合物層のかたさ值 $\left(H_{T} 600\right)$ が他の処理飞比 ベて若干低いのは Figs. 2 および7からもかかるよう にこの層は多孔質なためであるう。

このようにSKD 11 にタフトライド処理すると最表 面上り若干内部の添らがかたさ值は高く，から，Fig. 8 の衝撃破面で乎及られるように化合物層は柱状に成 長して特り，表面近傍はかなり多孔質になっている。 また実用面でも最表面を研摩して Fe 窒化物を除去し た状態で使用される場合が多いため，本研究では Fe 窒化物を除去したかたさ值を表面かたさと定義した。

これらの定義に基ら゙き, 各タフトライド处理時間に捛 ける表面かたさ，心部かたさ，硬化深さをまるるて

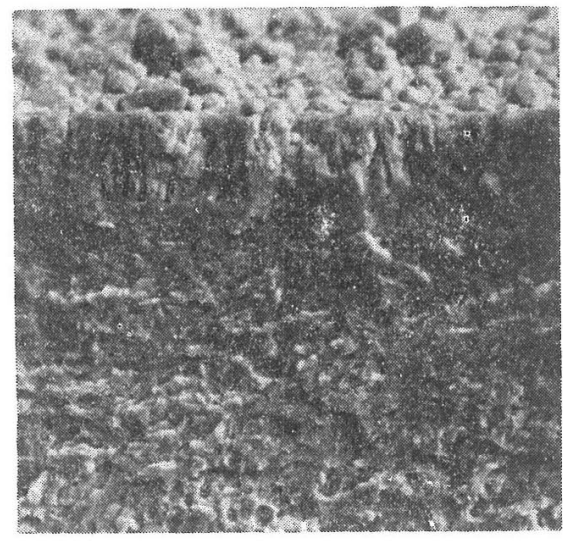

Fig. 8. Impact fracture surface of 12 hours tufftrided specimen.

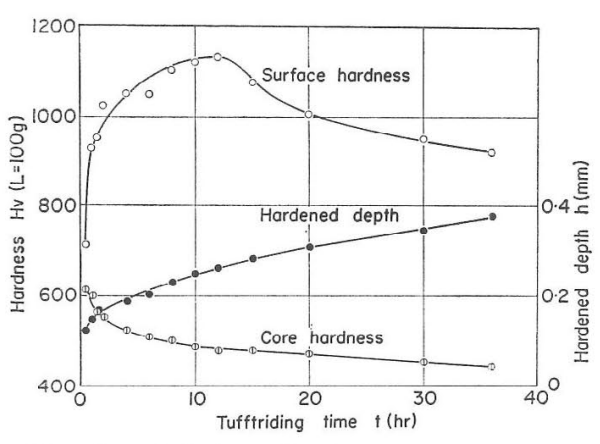

Fig. 9. Variations of surface hardness, core hardness and hardening depth due to tufftriding time.

Fig. 9 亿示す. 表面かたさは約12時間で最高値々なり, 气れ以上処理時間が長くなると低下している。この低 下の原因としては, Fig.2の組織にもみられるように， 時間の経過と共に化合物層 $\left(\mathrm{Fe}_{3} \mathrm{~N}, \varepsilon \mathrm{Fe}_{3} \mathrm{~N}-\mathrm{Fe}_{2} \mathrm{~N}\right)$ 方 厚くなり，窒素の新たな浸入が妨げられすでに内部 で $\mathrm{Cr}$ 窒化物として存在する窒素が内部へ拡散するた めに, 表面近くの Cr 窒化物が減少することが考兑ら れる。したがって硬化深さはこのような窒素の拡散に より処理時間とともに大きくなる。心部のかたさ値は 処理温度 $570{ }^{\circ} \mathrm{C} て ゙$ 熱せられるために時間の経過ととる に焼もどし效果が現われ徐々に低下している。

\section{$4 \cdot 3$ 摩耗試験}

各タフトライド処理時間に物ける摩耗時間之全摩耗 量の関係の例を Fig. 10 飞示す.タフトライド処理に よって耐摩耗性は著しく改善されるが，タフトライド 処理時間によってその程度はかなり異なるようである。 特に摩耗時間 $2 \sim 4$ 時間程度屯では 0.5 時間タフトラ

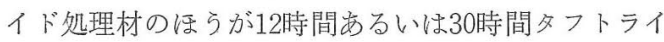

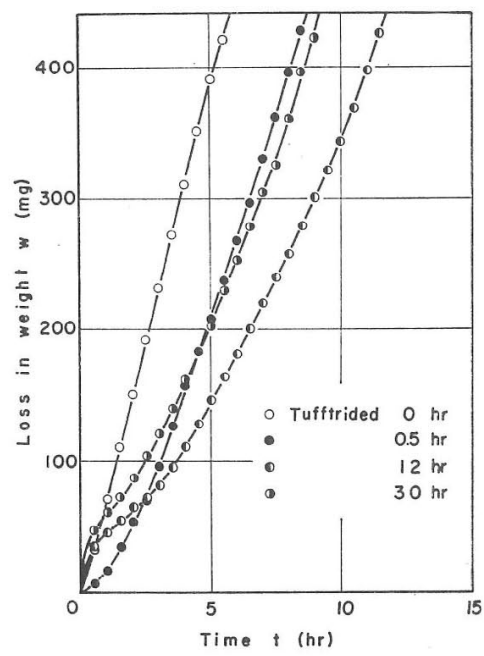

Fig. 10. Relation between wear time and loss in weight by wearing. 
ド処理材よりも摩耗量が少なく, 而摩耗性が良いとい った非常に興味深い結果となっている. 摩耗時間が 4 時間を越すと長時間のタフトライド処理材のほうが耐 摩耗性は良くなる。しかし，必ずしもタフトライド処 理時間が長いものほど耐摩耗性が改善されるわけでは なく, Fig. 10 から明らかになるように処理時間が 12 時間以上になると逆に耐摩耗性は低下する。そこで摩 耗時間が 8.5 時間までの全摩耗量を各タフトライド処 理時間で整理してみたのが Fig. 11 である.タフトラ イド処理していない焼入焼もどし材に比ベタフトライ ド処理されると耐摩耗性は良くなり, 特に 12 時間処理 材は最小の摩耗量を示し, それ以上処理時間が長くな ると摩耗量は増加し耐摩耗性が低下するのが明らかで ある・

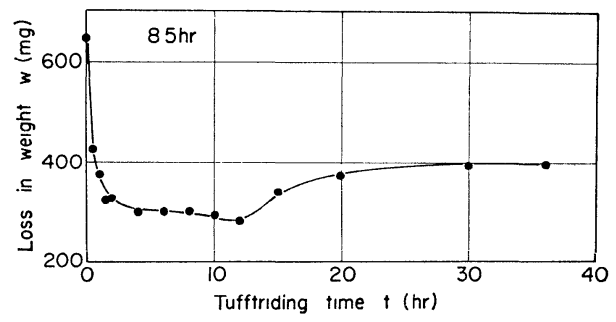

Fig. 11. Relation between tufftrided time and loss in weight by wearing at wear time of 8.5 hours.

摩耗初期（4時間以下）に打いて短時間のタフトラ イド処理材の汪らが長時間のタフトライド処理材より も摩耗量が少なく, 耐摩耗性が一見良好とみなされる 点および摩耗後期（ 4 時間以上）になると長時間処理 材のほうが耐摩耗性が良くなる点について若干検討し てみたい。 0.5 時間ごとの摩耗量別に整理した例を Fig. 12 に示す. 12時間あるいは30時間タフトライド 処理材の 0 〜 0.5 時間に和ける摩耗量は焼入焼もどし 材よりも大となっているが， 0.5 時間タフトライド処 理材では摩耗量はごくわずかである. そこで $0 \sim 0.5$ 時間までの摩耗量を各タフトライド処理時間で整理し

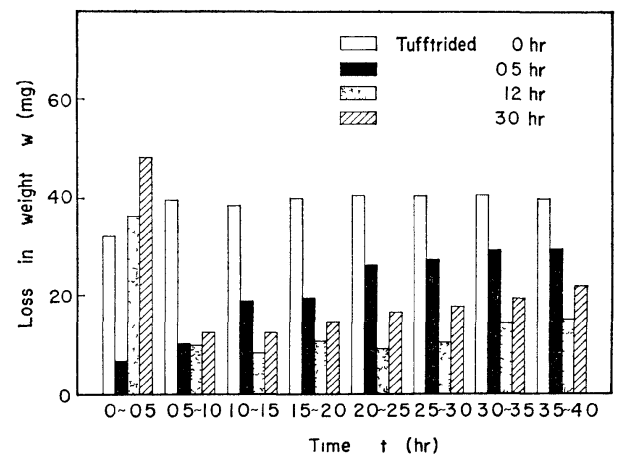

Fig. 12. Loss in weight measured every 0.5 hours.

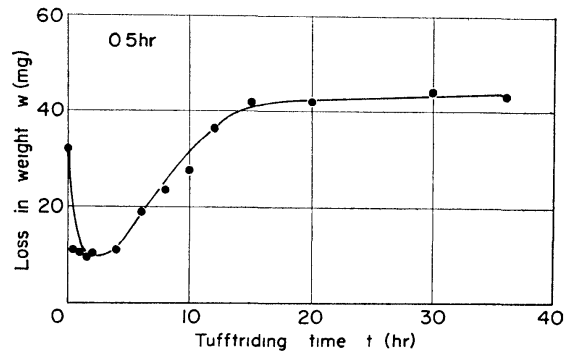

Fig 13. Relation between tufftrided time and loss in weight by wearing at wear time of 0.5 hours.

てみたのが Fig.13 である. 4 時間程度のタフトライ ド処理材までその摩耗量は焼入焼もどし材に比べて 非常にわずかである。しかし，それ以上処理時間が長 くなると摩耗量は急激に増加し，15時間以上になると 摩耗量はほぼ一定になる。そして12洔間以上処理され ると焼入焼もどし材よりも摩耗量は大となる。また，

Fig.11 から明らかなよらに摩耗時間が0. 5 時間以上に なると 0.5 時間ごとの摩耗量は 12 時間めるいは 30 時間 タフトライト処理材では著しく少なくなる.一方, 0.5 時間タフトライド処理材では摩耗時間が長くなるほど 0.5 時間ごとの摩耗量は増加し，焼入焼もどし材では 摩耗時間にかかわらず同程度である。したがって，長 時間タフトライド処理材（4時間以上のタフトライド 処理材）の最表面近くはかなり摩耗しやすい状態にあ り，処理時間が長くなるほどその傾向は著しいといえ る、そして，その部分が摩耗してしまらとその下は非 常に摩耗しにくい状態となっていると考えられる。こ のことはすでに述べてきたよらに最表面に形成される 一相目の化合物層のかたさ值はその直下，二相目の化 合物層や拡散層あるいは焼入焼もどし材よりも低いこ と，そして Fig.6 にみられたように多孔質などのた め乾燥摩耗に沶いてはかなり摩耗しやすいと考えられ る.また，Fig.13 から明らかなよらにタフトライド 処理時間が長くなると $0 \sim 0.5$ 時間 な゙の摩耗量が短 時間処理に比べて増加している.これは処理時間が長 くなるほど一相目の化合物層犺厚くなる．これらの点 について Fig. 14 に示した12時間タフトライド処理材 の摩耗粉の観察結果からもい方る.つまり， Fig. 14 (a)の摩耗初期（ $0 \sim 0.5$ 時間）の摩耗粉は薄板状（約 $200 \mu)$ で, 一相目の化合物層がはく離現象を起こし 容易に摩耗しやすいことを示している. そして Fig. 14(b)に示したように化合物層がなくなったと思われる とさ（4.5〜 5 時間）の拡散層の摩耗粉は細かい粒塊 状 (約 $20 \mu)$ となっており, 化合物層より摩耗しにく いことを示している，そして，化合物層表面のかたさ 值を示した Fig.9 の結果と Fig.11 の摩耗試験の 結 果と良く対応している。すなわち，表面かたさが高い 


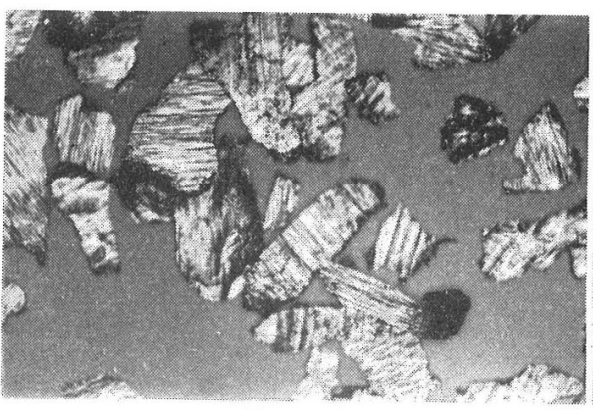

(a) $0 \sim 0.5 \mathrm{hr}$

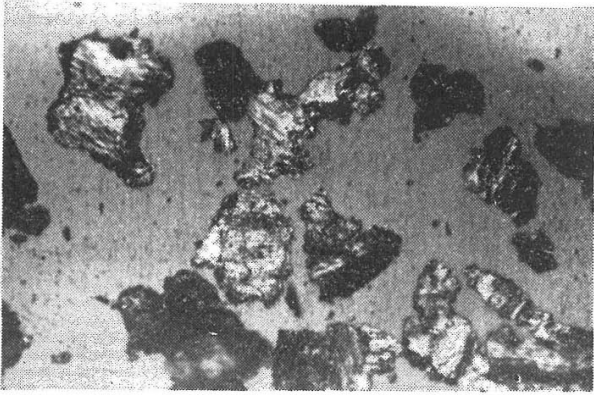

(b) $4.5 \sim 5.0 \mathrm{hr}$

Fig. 14. Photography of wear powder under wear test.

ものほど摩耗量は少なく，耐摩耗性が良くなっている。 本実験では表面かたさが高い12時間処理が最も良い結 果家している。

以上，タフトライド処理材の摩耗特性はそ旣摩耗初 期には一相目の化合物層形成の程度に，摩耗後期には 二相目の化合物層と拡散層の状態に支配されていると 教觉られる、そして，本実験のよう飞拡散層や母材上 り一相目の化合物層のかたさ値のほらが低い場合には 化合物畨は多フトライド処理に上る耐摩耗性の改善に 笴与せず，先の直下に二相目の化合物層之拡散層の表 面近くのかたさ值を高くするほど良い耐摩耗性定示す ことになる。したがって，Fig.10 やFig.12 にみら れるように摩耗初期で短時間処理のほうが耐摩耗性が 良好にみ元るが，実際の使用では摩耗状態でかなり長 く使用されることを考光ると，㐫る程度までは長い夕 フトライド処理のほらが有效とい党る。

\section{5 結論}

以上，本実験より以下の結論が得られた。

(1) 合金工具鋼 (SKD 11) にタフトライド処理を施 すと，最表面に $\mathrm{Fe}$ 窣化物 $\left(\mathrm{Fe}_{3} \mathrm{~N}, \quad \varepsilon \mathrm{Fe}_{3} \mathrm{~N}-\mathrm{Fe}_{2} \mathrm{~N}\right)$, 气の下に $\mathrm{Cr}$ 窒化物 $\left(\mathrm{CrN}, \mathrm{Cr}_{3} \mathrm{~N}\right)$ を主体とした二 層からなる化合物層が形成される。攵して化合物層直 下にできる拡散層は，粒界に沿って網目状に浸入して いる $\mathrm{Cr}$ 窒化物 $(\mathrm{CrN})$ 拉よび $\mathrm{Cr}$ 炭化物 $\left(\mathrm{Cr}_{7} \mathrm{C}_{3}\right)$ が 久ら机る。しかし，ASTM カードで同定できない化 合物当若干存在していた。

（2）一相目の化合物層のかたさ值は約 $H_{V} 600$, 二相 目の化合物層は約 $H_{V} 1300$ であり, その直下の拡散 層のか地さ值（12 時間タフトライド処理では約 $H_{V}$ $1200)$ に比べて一相目は低い。この一相目の化合物 層は，室温中の乾燥摩耗に扔いてははく離しやすく， 耐摩耗性向上には，二相目の化合物層々拡散層が笴与

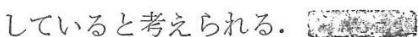
$\therefore-2=-214$

(3) タフトライド処理材の表面かたさと摩耗量の関 係はほぼ対応し，表面かたさが高くなるほど耐摩耗性
が向上する

（4）タフトライド处理時間としては，表面かたさが 最も高く，心部かたさがあまり低下せず，硬化深さむ 深いこと抒よび耐摩耗性が良いことより約12時間処理 が適当之考穴る。

なお，本研究遂行に每たり実験に協力された武蔵工 業大学学生 (当時) 高橋 昭, 小沢 隆, 師橋卓久, 岡富美男の四君に，また，タフトライド処理をご担当 いただいた日本パーカーライジング（株）勝田工場の 出川富男氏に謝意至する。

（昭和49年 5 月22日 日本材料学会第23期総会学術鹪演会にて講演）

参 考 文 献

1）高瀬孝夫，日本金属学会会報，14，99（1975）.

2）令井勇之進，香川博幸， 日本金属学会誌，30，290 (1966).

3）小川喜代一，金属材料，7，6，9（1967）

4）竹内栄一，金属材料， 7，6，19（1967）.

5）た之兄ば，浅見克敏，吉岡靖夫，寺沢正男，材料，22， 359 (1973).

6）高瀬孝夫，中村廉彦，鋳䤨造，9，17 (1974).

7）小川喜代一，金属表面技術，18，197（1967）.

8) Winteres, K., Durferrit Hausmitt, H. 34. S, 82 (1962),

9) Schreck, R., ZWP, H.11, S. 59, 515 (1964).

10) Winterer, K., Durferrit Hausmitt, H. 36. S, 24 (1964).

11) Eysell, F. W., Werkst. u. Betr, -H. 5. S, 98, 274 (1965).

12) Heinen : ZWP, H. 3. S, 59, 110 (1964).

13) Hiller, H. M., Giesserei, H.1. S, 50, 11 (1963).

14) Bungarbt, K., Arch. f. EHW, H. 5. S, 37, 381 (1966).

15）嵯峨卓郎，宮川大海，木吉国夫，相原民彦，材料， 12 , 521 (1963).

16）門間改三，矢島悦次郎，鉄鋼 III（1967）日本金属学会

17）寺沢正男，吉岡靖夫，浅見克敏，材料，16，991（1967）。

18）大黒 貴，金子 晨，日本金属学会誌，33，672（1969）。

19）菊地暽平，浅香忠夫，熱処理，14，1，23（1974）。 